\title{
United States v. Rosen: Pushing the Free Press onto a Slippery Slope?*
}

\section{INTRODUCTION}

It has been the subject of U.S. Supreme Court dicta' and congressional speculation, ${ }^{2}$ and lately, ripe fodder for punditry on both sides of the ideological aisle, but for all its answer could possibly portend, the question remains unsettled: Can the government constitutionally prosecute the media for revealing national security secrets in news stories, and if so, under what circumstances?

The Espionage Act of $1917^{3}$ would likely be the source of such prosecution. Passed at the onset of American involvement in World War One, the Act prohibits, among other things, the willful communication of "information relating to the national defense" that "the possessor has reason to believe could be used to the injury of the United States or to the advantage of any foreign nation" to "any person not entitled to receive it." ${ }^{, 4}$ Nowhere does the Act exempt the media from liability, and yet naturally, given the sacrosanct status of the country's free press, the government has been reluctant to prosecute the media under the Act's broad umbrella. With no cases before them, courts have not had an opportunity to determine whether such a charge would pass constitutional muster.

In dicta, the Supreme Court has suggested that such a prosecution would be constitutional, ${ }^{5}$ and building on that premise, in August 2006, the Eastern District of Virginia found in United States v. Rosen ${ }^{6}$ that prosecuting two lobbyists under the Act did not violate the lobbyists'

- Joe Bant. J.D. candidate 2008, University of Kansas School of Law; B.S. 2005, University of Kansas. I would like to thank Professor Mike Kautsch for his insight and suggestions in helping me develop this idea. I would also like to thank Matt Osman and Samia Khan for their editorial review and my family and friends for their support.

1. See infra Part II.B (discussing "Pentagon Papers" case).

2. See infra Part III.A (discussing congressional uncertainty about the implications of the Espionage Act).

3. 18 U.S.C. $\S \S 792-799(2000)$.

4. Id. $\S 793(\mathrm{e})$.

5. See infra Part II.B. (discussing the "Pentagon Papers" case).

6. 445 F. Supp. 2d 602, 641 (E.D. Va. 2006). 
right of free speech. ${ }^{7}$ While prosecuting a lobbyist is obviously not the same as prosecuting a newspaper or a television station, Rosen is nevertheless significant because it demonstrates the courts' willingness to enforce the Act against "those not in a position of trust with the government." ${ }^{18}$ In prior cases, such as United States v. Morison, ${ }^{9}$ the government had only targeted individuals it had authorized to access the information and who subsequently leaked it. ${ }^{10}$ The defendant in Morison, for example, worked at the Naval Intelligence Support Center and had a security clearance of "Top Secret-Sensitive Compartmented Information." 11 The lobbyists in Rosen, in contrast, had no clearance and arguably no responsibility to the government to keep the information private. $^{12}$

Nevertheless, the court in Rosen concluded that "both common sense and the relevant precedent point persuasively to the conclusion that the government can punish those outside of the government for the unauthorized receipt and deliberate retransmission of information relating to the national defense."13 The "relevant precedent" to which the court referred was New York Times Co. v. United States, ${ }^{14}$ the "Pentagon Papers" case, and specifically the dicta therein that specified the Act could impose liability on media outlets for publishing national securityrelated information. ${ }^{15}$

Given the volatile climate of today's "War on Terror" and the classified information that undoubtedly springs from the war in voluminous waves, it is only a matter of time before the Court has the opportunity to write more than dicta about the issue. Reporters Dana Priest of The Washington Post and James Risen and Eric Lichtblau of The New York Times won 2006 Pulitzer Prizes ${ }^{16}$ for breaking stories on secret government prisons in Europe ${ }^{17}$ and the National Security

7. Id. at 641 .

8. See id. at 637 (concluding that "the government can punish those outside of the government for the unauthorized receipt and transmission of information relating to the national defense").

9. 844 F.2d 1057 (4th Cir. 1988).

10. Id. at 1085 .

11. Id. at 1060 .

12. See Rosen, 445 F. Supp. $2 \mathrm{~d}$ at 636 (stating that the lobbyists "have not violated a position of trust with the government").

13. Id. at 637.

14. 403 U.S. 713 (1971)

15. See id. at 742 (stating that in some situations the government may invoke equity jurisdiction to prevent "publication of material damaging to 'national security").

16. The Pulitzer Prizes, http://www.pulitzer.org/2006/2006.html (last visited Apr. 12, 2007)

17. Dana Priest, CIA Holds Terror Suspects in Secret Prisons, WASH. POST, Nov. 2, 2005, at A1. 
Agency's (NSA) secret domestic wiretapping program, ${ }^{18}$ respectively, but there were those who said the reporters deserved jail time for revealing national security secrets. ${ }^{19}$

This Comment proposes to examine media liability under the Espionage Act, considering the history of the Act and balancing the issue of media liability against the legislative intent that created the Act, public policy, and the Constitution. Ultimately, the Comment will conclude that, in all three respects, the Espionage Act is a poor tool for holding media outlets liable because it is broad and unwieldy. The government should have some means to punish those who reveal secrets that by their revelation truly jeopardize national security, even when the culprits are newspapers or television stations, but in balancing the competing interests of the free press and national security, the Espionage Act tilts impermissibly in favor of the latter. Limits on the press, if they exist, should be as defined and as unrestrictive as the most vital interests of national security will allow.

\section{BACKGROUND: A BRIEF HISTORY OF THE ESPIONAGE ACT}

\section{A. Initial Enactment and Rejection of the Press Censorship Provision}

The Espionage Act of 1917 was passed at the beginning of American involvement in World War One ${ }^{20}$ as a response to Department of Justice (DOJ) concerns that "existing federal laws would be insufficient "to regulate the conduct of the individual during war time.",21 Specifically, the DOJ "wanted to repress 'political agitation . . . of a character directly affecting the safety of the state,' particularly 'disloyal propaganda' threatening the formation and maintenance of the armed forces." 22 Passage of the Act took "nine weeks of grueling debate," much of which focused on the Act's potential to conflict with the First Amendment. ${ }^{23}$

18. James Risen \& Eric Lichtblau, Bush Lets U.S. Spy on Callers Without Courts, N.Y. TimES, Dec. 16, 2005, at Al.

19. See infra note 41 and accompanying text.

20. Geoffrey R. Stone, Judge Learned Hand and the Espionage Act of 1917: A Mystery Unraveled, 70 U. CHI. L. REV. 335, 336 (2003).

21. David M. Rabban, The Emergence of Modern First Amendment Doctrine, 50 U. CHI. L. REV. 1205, 1217 (1983) (citing John Lord O'Brien, Civil Liberty in War Time, 42 REP. N.Y. ST. B. ASS'N 275, 299 (1919)).

22. Id. (citing $\mathrm{O}^{\prime}$ Brien, supra note 21 , at 277,300 ).

23. Geoffrey R. Stone, Perilous times: Free Speech in Wartime From the Sedition ACT OF 1798 TO THE WAR ON TERRORISM 151-52 (2004). 
None of the Act's provisions explicitly reference the media-neither admitting media liability nor excluding it; ${ }^{24}$ however, one might argue that the Act was passed with some deference to the "free press." When Congress originally considered the statute, it contained a "press censorship" provision that would have allowed the government to prosecute the press for publishing information that "the President, in his judgment, declared to be 'of such character that it is or might be useful to the enemy.",25

The majority of the press vehemently opposed the provision. ${ }^{26}$ Congress was more divided, trading arguments that remain familiar today. Supporters of the provision stressed placing trust in the Executive to take the necessary measures to protect national security. ${ }^{27}$ The opposition argued that the provision was contrary to values of American democracy. ${ }^{28}$ After fierce debate, Congress ultimately omitted the provision before passing the Act. ${ }^{29}$

Nevertheless, there are several provisions of the Act that the government could conceivably use against the press, a couple of which explicitly prohibit the "publication" of certain types of materials. For instance, $\S 794(\mathrm{~b})$ prohibits publication of certain defense-related information in "time of war, with intent that the same shall be communicated to the enemy." 30 Section 797 proscribes publishing and selling photographs of defense installations under certain circumstances, ${ }^{31}$ and $\S 798$, dealing with disclosure of classified

24. $I d$.

25. Stone, supra note 20 , at 345 .

26. See, e.g., Publishers Call for a Free Press; Declare That Only Restrictions Needed are Upon Messages Leaving the Country, N.Y. TIMES, Apr. 26, 1917, at 4 ("The American Newspaper Publishers Association, in annual convention assembled at the Waldorf-Astoria yesterday, passed a resolution urging upon Congress the elimination of the press censorship provision from the Espionage bill now pending. The vote was unanimous.").

27. Stone, supra note 20, at 347 (citing 55 CONG. REC. H1592 (daily ed. Apr. 30, 1917) (statement of Rep. Webb)).

28. Id. at 348 (citing 55 CONG. REC. H1773 (daily ed. May 11, 1917) (statement of Rep. Madden)).

29. Id. at 349 .

30. 18 U.S.C. $\S 794(b)(2000)$.

31. 18 U.S.C. $\$ 797(2000)$. This provision provides that:

On and after thirty days from the date upon which the President defines any vital military or naval installation or equipment as being within the category contemplated under section 795 of this title whoever reproduces, publishes, sells, or gives away any photograph, sketch, picture, drawing, map, or graphical representation of the vital military or naval installations or equipment so defined, without first obtaining permission of the commanding officer of the military or naval post, camp, or station concerned, or higher authority, unless such photograph, sketch, picture, drawing, map, or graphical representation has clearly indicated thereon that it has been censored by the proper 
information, proscribes publication of information encompassed within several delineated categories. ${ }^{32}$

The aforementioned provisions aside, ironically the provision of the Act that many view as posing the greatest threat to the media is one that does not reference "publication" at all: § 793(e). That provision, which Congress added in $1950,{ }^{33}$ effectively makes it illegal to have unauthorized possession of "national defense"-related information and to willfully convey that information. ${ }^{34}$ Its breadth compared with the rest of the Act makes it particularly threatening to the media outlet that dabbles in national security information. ${ }^{35}$ It is this particular provision that Judge Ellis expressly deems constitutional in his denial of the defendants' motion to dismiss in Rosen. ${ }^{36}$

military or naval authority, shall be fined under this title or imprisoned not more than one year, or both.

Id.

32. 18 U.S.C. $\S 798$ (a) (2000). Section 798(a) prohibits knowing and willful publication of classified information

(1) conceming the nature, preparation, or use of any code, cipher, or cryptographic system of the United States or any foreign government; or (2) concerning the design, construction, use, maintenance, or repair of any device, apparatus, or appliance used or prepared or planned for use by the United States or any foreign government for cryptographic or communication intelligence purposes; or (3) concerning the communication intelligence activities of the United States or any foreign government; or (4) obtained by the process of communication intelligence from the communications of any foreign government, knowing the same to have been obtained by such processes .... Id.

33. Harold Edgar \& Benno C. Schmidt, Jr., The Espionage Statutes and Publication of Defense Information, 73 COLUM. L. REV. 929, 942 (1973).

34. 18 U.S.C. $\S 793(\mathrm{e})(2000)$.

Whoever having unauthorized possession of, access to, or control over any document, writing, code book, signal book, sketch, photograph, photographic negative, blueprint, plan, map, model, instrument, appliance, or note relating to the national defense, or information relating to the national defense which information the possessor has reason to believe could be used to the injury of the United States or to the advantage of any foreign nation, willfully communicates, delivers, transmits or causes to be communicated, delivered, or transmitted, or attempts to communicate, deliver, transmit or cause to be communicated, delivered, or transmitted the same to any person not entitled to receive it, or willfully retains the same and fails to deliver it to the officer or employee of the United States entitled to receive it ....

Id.

35. See Edgar \& Schmidt, Jr., supra note 33, at 998 ("[T]hey [\$ 793(d) and (e)] are also the statutes that pose the greatest threat to the acquisition and publication of defense information by reporters and newspapers.").

36. United States v. Rosen, 445 F. Supp. 2d 602, 643 (E.D. Va. 2006). 


\section{B. Considering the Past Interplay Between the Espionage Act and the Press}

Few Espionage Act cases have even indirectly involved the press, and threats aside, the government has never prosecuted a media outlet under the Act for disseminating government secrets-despite innumerable news stories that have revealed classified information. ${ }^{37}$ The most recent examples that come to mind regarding prominent news stories that conceivably could have violated the Act were published in The New York Times ${ }^{38}$ and The Washington Post ${ }^{39}$ and dealt, respectively, with the NSA's secret domestic wiretapping program and secret government prisons in Europe. Both stories used classified information and prompted DOJ investigations. ${ }^{40}$ The government has yet to initiate any criminal proceeding, but there is no shortage of advocates who claim it has a legal right to do so. ${ }^{41}$

An older, equally pertinent example concerns the Pentagon Papers, which first The New York Times and then The Washington Post published in excerpts in $1971 .^{42}$ The Pentagon Papers were a top-secret study that essentially contained a history of American strategy in

37. Edgar \& Schmidt, Jr., supra note 33, at 1000 ("If these statutes mean what they seem to say and are constitutional, public speech in this country since World War II has been rife with criminality."). University of Chicago Law Professor Geoffrey Stone notes a couple of occasions when the government used the Act to prosecute German-American newspapers during the First World War, but these prosecutions dealt more with sedition than government secrets, and so are not really analogous to the situation addressed here. See STONE, supra note 23, at 210 (citing Schaefer v. United States, 251 U.S. 466, 482 (1920) (upholding conviction of three men associated with a German-American newspaper for translating English stories to reflect a bias in favor of the Germans); Berger v. United States, 255 U.S. 22 (1921) (reversing, on procedural gounds, a criminal conviction of a former editor of a German-American newspaper whom the government accused of publishing anti-American editorials))

38. Risen \& Lichtblau, supra note 18

39. Priest, supra note 17 .

40. Nat Hentoff, Chilling Free Speech, WASH. TIMES, May 8, 2006, at A18.

41. See, e.g., Michael Barone, The Reach of the Espionage Act, Mar. 1, 2006 $\mathrm{http} / / / \mathrm{www}$.usnews.com/usnews/opinion/baroneblog/archives $/ 060301 /$ the_reach_of_th.htm (last visited Apr. 20, 2007) ("[T] hat the conduct of the Times and its sources in government is covered by these statutes is, I think, irrefutable."); Andrew C. McCarthy, Reporters and Investigations, NAT'L REV. ONLINE, Apr. 25, 2006, http://search.nationalreview.com (search "Search Terms" for "Reporters and Investigations"; then follow "Reporters and Investigations" hyperlink under "Search Results") (last visited Apr. 20, 2007) (arguing that the newspaper stories about the NSA wiretaps and secret government prisons in Europe constitute situations where the "reporters are theoretically complicit in criminal activity"); Gabriel Schoenfeld, Has the "New York Times" Violated the Espionage Act, COMMENT. MAG., Mar. 2006, at 23. Schoenfeld advocates holding the media accountable for news stories containing national security secrets, although he is critical of the Espionage Act. Gabriel Schoenfeld, Op-Ed., Weak on Leaks, L.A. TIMES, May 21, 2006, at M1.

42. David Rudenstine, The Day the Presses Stopped: A History of the Pentagon PAPERS CASE 1-2 (1996). 
Vietnam. ${ }^{43}$ The federal government tried to halt publication of the material by petitioning for an injunction. ${ }^{44}$ The case quickly made its way to the Supreme Court and ultimately spawned ten different opinions. ${ }^{45}$ Despite denying the government its requested injunction, three of the concurring opinions seemed to affirm at least the possibility of prosecuting the newspaper under the Espionage Act. ${ }^{46}$ For whatever reason, the government declined to do so, and the Court never had the opportunity to turn its dicta into a holding. ${ }^{47}$

The "Pentagon Papers" case notwithstanding, an Espionage Act prosecution never directly implicated the media until United States $v$. Morison. ${ }^{48}$ The case concerned a former employee of the Naval Intelligence Support Center (NISC) who stole and released secret photographs of a Soviet aircraft carrier to an English periodical. ${ }^{49}$ The court dismissed the defendant's contentions that the Act did not prohibit unauthorized leaks of information to the press. ${ }^{50}$ The court also rejected the defendant's claims that the Act was unconstitutionally vague and overbroad. $^{51}$ Although Morison was not a case of the government directly prosecuting the media, commentators nevertheless viewed it as a threat to the right to publish national security information. ${ }^{52}$

Rosen is the latest chapter in the saga, and it takes the Morison threat a step further by affirming the constitutionality of using the Act to prosecute individuals who were not the source of the initial leak and who never had authorized access to the leaked information. ${ }^{53}$

\footnotetext{
43. Id.

44. Id. at 2 .
}

45. See N.Y. Times Co. v. United States, 403 U.S. 713, 714, 720, 724, 727, 730, 740, 748, 752, 759 (1971) (including a per curiam opinion and nine individual opinions).

46. See id. at 730 (Stewart, J., concurring) (noting Congress can enact laws to protect government secrets); id. at 733-34 (White, J., concurring) (arguing that the Congress that enacted the Act felt newspapers could be subject to prosecution); id. at 745 (Marshall, J., concurring) (quoting the Act as criminalizing the publication of information relating to the national defense).

47. RUDENSTINE, supra note 42, at 343.

48. 844 F.2d 1057 (4th Cir. 1988).

49. Id. at $1060-62$.

50. Id. at 1070 .

51. Id.

52. See, e.g., David H. Topol, Note, United States v. Morison: A Threat to the First Amendment Right to Publish National Security Information, 43 S.C. L. REV. 581, 590-91 (1992) ("Morison's conviction raises an obvious issue concerning the erosion of First Amendment rights by prosecuting individuals who leak to the press.").

53. United States v. Rosen, 445 F. Supp. 2d 602, 637 (E.D. Va. 2006). 


\section{Looking at Rosen}

1. Underlying Facts of the Case

The defendants in Rosen are former employees of the American Israel Public Affairs Committee (AIPAC), an organization that lobbies the American government on behalf of Israeli interests. ${ }^{54}$ In its indictment, the government alleged that the former lobbyists "cultivated relationships with government officials with access to sensitive U.S. government information, including [national defense information], ... obtained the information from these officials, and ... transmitted the information to persons not otherwise entitled to receive it, including members of the media, foreign policy analysts, and officials of a foreign government." 55 Neither of the lobbyists had any sort of security clearance that would have authorized them access to the information in question. ${ }^{56}$ In all cases, they obtained the information from government officials with such clearance who willingly divulged it. ${ }^{57}$ There is no accusation that they stole the information or used any kind of illegal means to acquire it. The information related to a variety of foreign policy issues, including terrorism in Central Asia, U.S. strategy in the Middle East, and Al-Qaeda. ${ }^{58}$ In all cases, the two defendants appeared to know they were dealing with highly sensitive and classified material.

They responded to the suit by attacking its constitutionality on three grounds. First, they claimed that the "prosecution violates the Fifth Amendment's Due Process Clause under the vagueness doctrine because [the Espionage Act's] indeterminate language failed to provide [them] with adequate warning that their conduct was proscribed." 59 Second, they argued that the prosecution violated their First Amendment rights of free speech and to petition the government. ${ }^{60}$ Finally, they claimed that the statute was unconstitutionally overbroad. ${ }^{61}$ The court, citing the government's compelling interest in protecting the country's national security, rejected all three arguments and found the statute to be constitutional. ${ }^{62}$

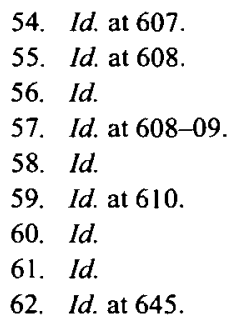




\section{Significance of the Case's Implications}

Rosen, at this point, is far from a Supreme Court precedent, and even supposing it circulates through the appellate process and attains such status, it is still not a case of the government prosecuting the press. Nevertheless, the government in Rosen essentially aims to punish the defendants, who lacked security clearance, for listening to, receiving, and communicating sensitive information-something members of the media do routinely in reporting news stories about national and international affairs. Opening up the door for Espionage Act prosecutions of nongovernment officials effectually opens up the door for using the Act to go after members of the media. If Judge Ellis's decision survives appeal, all that is left is for the government to put the theory into practice by bringing a newspaper or television station into court.

\section{ANALYSIS: PROBLEMS WITH ROSEN AND WITH THE GENERAL NOTION OF MEDIA LIABILITY UNDER § 793(e).}

\section{A. Introductory Overview}

Whatever the logic of the Rosen decision, the constitutionality of $\S$ 793(e) and its suitability for the problem at hand are far from foregone conclusions. Judge Ellis concedes that the section provides a "more difficult question" with respect to reconciling its mandate with the First Amendment, but relies on the persuasive line of logic that the government needs to have some mode of recourse to stop subsequent communication of national defense-related information once an initial leak has occurred. ${ }^{63}$

Ellis's reasoning may be difficult to dispute. Surely the government does need some method to stop the ripple effect of the first leak. The question is whether $\S 793(\mathrm{e})$ of the Espionage Act is the right tool for the job. Not even Congress really knows what the government can and cannot do under the Act's authority. Pondering the possibility of using the Act against the press, Senator Arlen Specter said, in a May 2, 2006

63. Id. at 637. Judge Ellis wrote:

In essence, [the defendants'] position is that once a government secret has been leaked to the general public and the first line of defense thereby breached, the government has no recourse but to sit back and watch as the threat to the national security caused by the first disclosure multiplies with every subsequent disclosure. This position cannot be sustained. 
senate judiciary committee hearing, that determining whether the government could prosecute the media under the Act was "a serious question [requiring] oversight and consideration of congressional intent." ${ }^{\text {"64 }}$ Former U.S. Attorney General Alberto Gonzales said there was "a possibility" that the government could use the Act against the media. ${ }^{65}$ Yet read the straight language of the statute itself, and the answer to the question would seem to be a definitive "yes." 66 The media can satisfy the requisite elements of the offense; they enjoy no statutory immunity - so why all the hesitation about holding them liable? The answer to that question seems to revolve around three considerations: the Constitution, congressional intent in passing the Act, and public policy.

\section{B. Analyzing the Constitutionality of $\$ 793(e)$ and its Application to the Media}

\section{The Vagueness Doctrine}

The first constitutional challenge that the defendants in Rosen raise against $\S 793(\mathrm{e})$ is the claim that the statute violates due process requirements because of its vagueness. ${ }^{67}$ The essence of the vagueness argument, which courts have considered before in the Espionage Act context, ${ }^{68}$ is that the "Fifth Amendment prohibits punishment pursuant to a statute so vague that 'men of common intelligence must necessarily guess at its meaning and differ as to its application.",69 This sort of vagueness, however, is not necessarily fatal because courts may clarify

64. Susan Burgess, The Big Chill: An Espionage Act Case in a Virginia Federal Court Exposes the Murky Standards Governing National Security Discussions, NEws MEDIA \& L., Spring 2006, at 4.

65. Scott Sherman, Chilling the Press, NATION, July 17, 2006, at 4.

66. The text of the statute reads:

Whoever having unauthorized possession of, access to, or control over any document, writing, code book, signal book, sketch, photograph, photographic negative, blueprint plan, map, model, instrument, appliance, or note relating to the national defense, or information relating to the national defense which information the possessor has reason to believe could be used to the injury of the United States or to the advantage of any foreign nation, willfully communicates, delivers, transmits or causes to be communicated, delivered, or transmitted, or attempts to communicate, deliver, transmit or cause to be communicated, delivered, or transmitted the same to any person not entitled to receive it, or willfully retains the same and fails to deliver it to the officer or employee of the United States entitled to receive it ... [s]hall be fined under this title or imprisoned not more than ten years, or both.

18 U.S.C $\$ 793(\mathrm{e})(2000)$.

67. Rosen, 445 F. Supp. 2d at 610.

68. See infra text accompanying notes $73-80$

69. Rosen, 445 F. Supp. 2d at 617 (quoting United States v. Lanier, 520 U.S. 259, 266 (1997)) 
the statute with judicial construction. ${ }^{70}$ In this case, in pertinent part, the defendants allege that the phrase in the statute "information relating to the national defense" is impermissibly ambiguous. ${ }^{71}$ Judge Ellis concedes that "it has long been recognized that the phrase "information relating to the national defense' is quite broad and potentially too broad since, especially in time of war, any information could conceivably relate to the national defense." ${ }^{, 72}$ However, he responds to the defendants' contention by invoking precedents that appear to have already settled the issue by narrowing the phrase through judicial construction.

In Gorin v. United States, ${ }^{73}$ the Supreme Court considered a similar vagueness challenge to the same phrase in $\S 2(\mathrm{a})$ of the Espionage $\mathrm{Act}^{74}$ and proposed to limit the phrase by restricting its application to information "closely held by the government."75 Judge Ellis also cites Morison, which essentially echoes Gorin, adding that the information cannot have been "made public" or "available to the general public.,"76 Morison also requires that "information related to the national defense" be " "potentially damaging to the United States or useful to an enemy of the United States.",77 The second limitation, Ellis writes, is important because it "assures that the government cannot abuse the statute by penalizing citizens for discussing information the government has no compelling reason to keep confidential." 78

The defendants also assert their vagueness argument with respect to the phrase "entitled to receive" in the provision, effectively claiming that the provision is unclear regarding who is entitled to receive national defense information. ${ }^{79}$ The court in Morison considered a similar contention and found that the Executive Branch determined who was entitled to receive national defense information by virtue of its classification system. ${ }^{80}$ Hence, by designating certain information as secret and subsequently granting certain officials clearance to gain access to the information, the Executive answers the question of entitlement.

70. Id. at 618 (citing United States v. Morison, 844 F.2d 1057, 1071 (4th Cir. 1988) ("[A]11 vagueness may be corrected by judicial construction ....")).

71. Id. at 618-22.

72. Id. at 618 .

73. 312 U.S. 19 (1941).

74. Id. at 28. Section 2(a) is now codified at 18 U.S.C. $\S 794(\mathrm{a})$ (2000).

75. Rosen, 445 F. Supp. $2 \mathrm{~d}$ at 618 (citing Gorin, 312 U.S. at 28).

76. Id. at 620 (quoting United States v. Morison, 844 F.2d 1057, 1071-72 (4th Cir. 1988)).

77. Id. at 621 (quoting Morison, 844 F.2d at 1071-72).

78. Id.

79. Id. at 622 .

80. Morison, 844 F.2d at 1074 (cited in Rosen, 445 F. Supp. 2d. at 622). 
The defendants in Rosen put an interesting spin on the argument that the Morison court did not have occasion to consider, specifically arguing that because they often received their information orally from their government sources, they did not know what was classified and thus did not have notice that they were not entitled to receive the information. ${ }^{81}$ The court dispatches this argument easily, at least in the context of vagueness, by referring to the provision's culpability requirement. Judge Ellis notes that the provision only authorizes liability for willful conduct. ${ }^{82}$ Thus, Ellis reasons, the statute is definitively clear on the consequence of the defendants' potential ignorance. If they did not know that they were not entitled to receive the information, they would not be acting willfully and would not be liable.

Whether Judge Ellis's construction of $\S 793(\mathrm{e})$ resolves the issue of vagueness is unclear. Before Morison, Columbia Law Professors Harold Edgar and Benno C. Schmidt, Jr. wrote that the "broad literal meaning of the subsection[] is almost certainly unconstitutionally vague and overbroad." 83 In response to Morison's purported narrowing of the subsection, they concluded that the net effect was simply criminalization of disseminating all classified materials, a scheme that Congress did not intend with the Act and one that it had expressly rejected on prior occasions. $^{84}$

Considering the Morison court's construction of "information related to national defense," Maryland Law Professor Peter E. Quint observed that "a formula of such breadth could cover almost all classified information." "Pr Professor Quint keys on the court's requirement that the information "is 'potentially' injurious to the country or 'might be useful to an enemy[,]" commenting on the limitation's embrace of even "remote 'potential' injur[ies]." ${ }^{86}$ In making this observation, Quint strikes at the root of the statute's vagueness problem, which also extends to the provision's scienter requirement.

At least for wrongful communication of intangible national defense information, the statute requires the actor to have "reason to believe [that the information] could be used to the injury of the United States or to the

81. Rosen, 445 F. Supp. 2d at 622.

82. Id. at 625 .

83. Edgar \& Schmidt, Jr., supra note 33, at 1000.

84. Harold Edgar \& Benno C. Schmidt, Jr., Curtiss-Wright Comes Home: Executive Power and National Security Secrecy, 21 HARV. C.R.-C.L. L. REV. 349, 399 (1986).

85. Peter E. Quint, Reflections on the Separation of Powers and Judicial Review at the End of the Reagan Era, 57 GEO. WASH. L. REV. 427, 449 (1989).

86. Id. 
advantage of any foreign nation." 87 This phrase is doubly important because besides forming the basis of part of the provision's scienter requirement, ${ }^{88}$ Morison effectively rolls it into the definition of what constitutes national defense information as well, by purporting to limit the term to only encompass information that could potentially harm the United States or aid their enemies. Yet neither the courts nor the statute define injury or put any parameters on the term or require any degree of probability that communicating the information will result in the injury. What does an "injury" in this context entail? ${ }^{89}$ What constitutes an "advantage" to a foreign nation? Clearly there are examples that most would consider obvious-revealing that intelligence operatives have cracked an enemy's code, for example, or relaying information that the country is planning a surprise attack before it happens-but many other instances are far more nuanced, perhaps allowing the government too much discretion in defining what constitutes an "injury."

This latitude connects to at least one of the vagueness doctrine's rationales: disallowing statutes that by their vagueness encourage "retaliatory or discriminatory application of the law." The press, in particular, by playing its role as government critic, naturally opens itself up to potential government retaliation. Juxtapose this with the morestringent-than-usual vagueness test that courts apply when the statute in question interferes with speech or expression ${ }^{91}$ and it seems clear that speech, in general, and the press, in particular, deserve at least a more precise statute.

\section{The Overbreadth Doctrine}

The essence of a First Amendment overbreadth argument is that an expression-limiting statute is impermissibly broad in the sense that it "punishes a 'substantial' amount of protected free speech, 'judged in relation to the statute's plainly legitimate sweep." "92 While not precisely analogous to the vagueness argument, the overbreadth concept overlaps

87. 18 U.S.C. $\S 793(\mathrm{e})(2000)$.

88. Id.

89. See Anthony R. Klein, National Security Information: Its Proper Role and Scope in a Representative Democracy, 42 FED. COMM. L.J. 433, 439 (1990) ("[W] United States? How grievous must the injury be?').

90. Mardee Sherman, Note, Chaos in the Marketplace: When Subsequent Punishment Leads to Prior Restraint: Will Cincinnati Ever Get It Right?, 32 N. KY. L. REv. 397, 421 (2005).

91. Id. (citing Hoffman Estates v. Flipside, Hoffman Estates, Inc., 455 U.S. 489, 499 (1982)).

92. Virginia v. Hicks, 539 U.S. 113, 118-19 (2003) (citing Broadrick v. Oklahoma, 413 U.S. $601,615(1973))$. 
to some extent because overbroad statutes, even when their language seems deceptively precise, are inherently vague.

However certain the literal terms, actors are not given fair warning ahead of conduct as to the permissible reach of statutory burdens. A person contemplating action within the literal scope is left in doubt whether his claim of privilege will be upheld, unless his situation is on all fours with that of an earlier claimant.

The result is a chilling effect on protected speech, because in deference to the overbroad statute, people will abstain from any speech that might be proscribed. With respect to the Espionage Act, the chilling effect derives from the same language that lies at the roots of the statute's vagueness: specifically, its overbroad embrace of information and materials relating to the national defense and the ambiguity regarding what constitutes harm or injury to the United States or an advantage to a foreign country. ${ }^{94}$

Thus, unsurprisingly, Judge Ellis's rejection of the overbreadth argument in Rosen substantially echoes his refutation of the earlier vagueness argument. He essentially recites the elements of the offense, concluding that the "statute is narrowly and sensibly tailored to serve the government's legitimate interest in protecting the national security.",95 Judge Ellis's conclusion here rings with a certain level of irony considering that he ends his opinion with the seemingly contradictory call to Congress to revise the statute, declaring that

to even the most casual observer ... the time is ripe for Congress to engage in a thorough review and revision of these provisions to ensure that they reflect ... contemporary views about the appropriate balance between our nation's security and our citizens' ability to engage in public debate about the United States' conduct in the society of nations. ${ }^{96}$

If Judge Ellis really feels this way, one wonders why he did not initiate the "review and revision" himself, by recognizing the validity of the vagueness and overbreadth contentions.

In any case, his rejection of the overbreadth argument is questionable for the same reason that his vagueness rejection is questionable: it fails to resolve or even address the scope of what "could harm the United States

93. Note, The First Amendment Overbreadth Doctrine, 83 HARV. L. REV. 844,872 (1970).

94. 18 U.S.C. $\S 793(\mathrm{e})(2000)$.

95. United States v. Rosen, 445 F. Supp. 2d 602, 643 (E.D. Va. 2006).

96. Id. at 646 . 
or aid a foreign nation." The lack of resolution here affects the breadth of the judicially modified phrase "information related to the national defense" and the breadth of the scienter requirement, which, with respect to intangible information, requires the defendant to have "reason to believe" the information could be harmful to the United States or advantageous to a foreign country.

Admittedly, Rosen does appear to give some limiting effect to the scienter requirement by incorporating into the analysis an element of "bad faith," which it traces back to Gorin-but exactly what limiting effect this incorporation actually has, or if a "bad faith" standard is even appropriate in $\S 793(\mathrm{e})$, is unclear. Gorin considered a section of the Espionage Act that required stricter culpability, specifically that defendants acted with "intent or reason to believe that the information to be obtained is to be used to the injury of the United States, or to the advantage of any foreign nation. ${ }^{, 97}$ Of this phrase, Justice Reed wrote that it "requires those prosecuted to have acted in bad faith." analysis makes sense in the context of Gorin because the statutory requirement implies some sort of bad-faith motive-not just a basis for knowledge that harm might occur, but something akin to complicity in the harm that could occur. In the broader "could be used" context of $\S$ 793(e), the potential impact of a bad-faith requirement is ambiguous. Judge Ellis asserts that it helps cure any vagueness or overbreadth challenges because, at least with respect to intangible information, it requires that the actor have a "bad faith purpose to either harm the United States or to aid a foreign government" or at least a reckless disregard of the probability that disclosure will have that effect. ${ }^{99}$ Of all the supposed limitations that judicial construction has placed on the Act, this is the most persuasive defense to vagueness and overbreadth claims, because whatever the breadth of the provision, it at least seems to require some proof of recklessness or bad motive. However, it presumably only applies to intangible information, and the more general "willfulness" standard applies to everything else.

Judge Ellis also gives a limiting effect to "willfulness," and there is some evidence in his opinion that he intends to impose similar culpability requirements on the communication of both tangible and intangible information. ${ }^{100}$ Such a merger could potentially have a

97. Gorin v. United States, 312 U.S. 19, 27-28 (1941) (emphasis added).

98. Id. at 28 .

99. Rosen, 445 F. Supp. $2 d$ at 626.

100. See, e.g., id. at 625 (noting that, even with respect to the disclosure of tangible information, the government must prove that the defendants willfully violated the Act). 
significant limiting effect on the scope of the statute, but ultimately, Judge Ellis maintains the statutory distinction. The Supreme Court has, in certain contexts, defined "willfulness" to require a "bad motive"101 or "evil motive," 102 but the furthest Rosen deigns to go is to equate willfulness with "specific intent to do something that the law forbids." 103 This is not the same as the aforementioned bad-faith requirement that the actor actually intend to harm the United States or aid a foreign government, and Judge Ellis makes the distinction clear with the following illustration:

For example, if a person transmitted classified documents relating to the national defense to a member of the media despite knowing that such an act was a violation of the statute, he could be convicted for "willfully" committing the prohibited acts even if he viewed the disclosure as an act of patriotism. By contrast, the "reason to believe" scienter requirement that accompanies disclosures of information, requires the government to demonstrate the likelihood of defendant's bad faith purpose to either harm the United States or to aid a foreign government.

Thus, Judge Ellis preserves the difference in treatment between tangible and intangible information. While interpreting willfulness to require specific intent has some limiting effect on the statute, it does not cure the vagueness or overbreadth problems. It still does not clarify what specifically constitutes harm to the United States or aid to a foreign government, and, at least with respect to tangible information, it still seems to threaten liability to anyone familiar with the broad prohibitions of the Espionage Act who disseminates national security information to an audience not authorized to receive it.

Judge Ellis notes that sustaining the subsection rests on the presumption that the government will only apply it to "situations in which national security is genuinely at risk," 105 but such a limitation hardly provides notice to journalists when both the statute and the courts refuse to delve further into what the law means by "risk." Ellis renders the warning toothless by using it to advocate a jury instruction that simply repeats the language of the statute instead of making any effort to

101. United States v. Murdock, 290 U.S. 389, 394 (1933).

102. Spurr v. United States, 174 U.S. 728,734 (1899).

103. Rosen, 445 F. Supp. 2d at 625 n.30 (quoting United States v. Morison, 844 F.2d 1057, 1071 (4th Cir. 1988)).

104. Id. at 626

105. Id. at 639 . 
clarify the gravity or type of risk needed to justify a guilty verdict. ${ }^{106}$ Thus, the court leaves the jury with a purportedly narrower instruction that, in actuality, the government can still twist at will to encompass all "information [that] is both classified and secret." 107 Surely, there are less invasive means of protecting national security than a provision that potentially has the effect of criminalizing the communication of any classified information, and surely such an act portends the type of chilling effect that the overbreadth doctrine serves to prevent.

\section{First Amendment Right of Free Speech}

The other significant constitutional argument that the defendants make in Rosen with respect to analyzing the media's liability under the Act is the more specific contention that applying $\S$ 793(e) to them violates their First Amendment right to free speech. ${ }^{108}$ It is in his analysis of this argument that Judge Ellis addresses the issue of applying the statute to nongovernment officials, or as he puts it: those who "have not exploited a relationship of trust to obtain the national defense information they are charged with disclosing, but instead [have] generally obtained the information from one who has violated such a trust." 109

The implications of his decision, as it relates to the media, are particularly apparent because the primary precedent he relies on is the "Pentagon Papers" case, ${ }^{110}$ which was a media case. In finding for The New York Times in that case, the Supreme Court rested much of its conclusion on the distinction in First Amendment jurisprudence between prior restraints and subsequent punishments. ${ }^{111}$ Thus, while the Court denied the government's request for an injunction (a prior restraint) prohibiting the Times from publishing, at least three of the concurring

106. Id. at 639 ("Judge Wilkinson and Judge Phillips in Morison insisted on the need for a jury instruction limiting 'information relating to the national defense' to information 'potentially damaging to the United States or ... useful to an enemy of the United States."') (citing Morison, 844 F.2d 1057, 1084 (Wilkinson, J., concurring)).

107. Edgar \& Schmidt, Jr., supra note 84, at 399.

108. Rosen, 445 F. Supp. $2 \mathrm{~d}$ at 610.

109. Id. at 635 .

110. N.Y. Times Co. v. United States, 403 U.S. 713 (1971).

111. See, e.g., id. at 733 (White, J., concurring) ("[T]erminating the ban on publication of the relatively few sensitive documents the Government now seeks to suppress does not mean that the law either requires or invites newspapers or others to publish them or that they will be immune from criminal action if they do."). The Court has interpreted the First Amendment "as providing greater protection from prior restraints than from subsequent punishments." Alexander v. United States, 509 U.S. 544, 554 (1993). 
justices seemed to reason that prosecuting the Times under the Espionage Act after it published the information (a subsequent punishment) would be constitutionally permissible. ${ }^{112}$

One can hardly fault Judge Ellis for his acceptance of the Court's dicta in this case. As he points out in his opinion, "lower courts 'are bound by the Supreme Court's considered dicta almost as firmly as by the Court's outright holdings, particularly when, as here, a dictum is of recent vintage and not enfeebled by any subsequent statement." 113

The problem, therefore, rests with the actual "Pentagon Papers" dicta. Rather than thoroughly examining the Act and its constitutionality, the Justices appear to rest their conclusions primarily on the abstract delineation of the law of prior restraints and subsequent punishments, in effect making the very unremarkable declaration that subsequent punishments are easier to justify than prior restraints.

The Espionage Act is used by the Court to fill in the blanks. In essence, after combing the annals of statutory authority, the Court saw the Act as the appropriate subsequent punishment to fit the kind of situation at hand. And thus, the Court appeared to impart the government with authority it had never before and has not since attempted to exercise.

The problem with using the "Pentagon Papers" case as a precedent in favor of using $\S 793$ (e) to prosecute the media is that it glosses over the constitutional counterarguments, which the Court had no reason to consider because the issue was not before it. At least with the justices who advocated use of the Espionage Act to prosecute the media, the theme-excepting, of course, the Court's firm rejection of prior restraints-was pronounced deference to this amorphous conception of "national security." Only Justice Black seemed to recognize the real nature of the problem, declaring that "[t]he word 'security' is a broad, vague generality whose contours should not be invoked to abrogate the fundamental law embodied in the First Amendment." 114

Instead of taking the opportunity to refine the term and the permissibility of First Amendment infringement in the name of its protection, the Court "did little to clarify the definition of national security or establish guidelines the government could follow to safeguard

112. See supra note 46 and accompanying text (discussing prosecution of newspapers under the Espionage Act).

113. Rosen, 445 F. Supp. 2d at 639 (citing McCoy v. Mass. Inst. of Tech., 950 F.2d 13, 19 (1st Cir. 1991)).

114. N.Y. Times Co., 403 U.S. at 719 (Black, J., concurring). 
its interests." 115 As such, it provided general support for the proposition that the government can use $\S 793$ (e) to prosecute the press, but it did this without properly explicating the constitutional principles underlying its decision.

Typically, courts subject speech restrictions to what is essentially a two-pronged analysis. They look at the legitimacy of the government interest that the restriction serves and the scope of the restriction relative to the interest-i.e., whether it extends beyond what is necessary to protect the interest. ${ }^{116}$ Courts apply this general analysis regardless of whether the restriction is content-based or content-neutral, ${ }^{117}$ although they grant the government more latitude with restrictions they view as content neutral. ${ }^{118}$ Even these lesser scrutinized restrictions, however, should still encompass a scope "no greater than [what] is essential to the furtherance of [the government] interest." 119

With respect to the Espionage Act, clearly national security is an important and often compelling government interest worthy of protection. Yet, judicial decisions analyzing the Act seem to wholly skip over the second part of the analysis, never deigning to question whether a less restrictive means would accomplish the same purpose. It is almost as if, simply by uttering the mantra of "national security," the government can push further First Amendment analysis out the window. ${ }^{120}$

115. Klein, supra note 89 , at 443 .

116. See Ashcroft v. Am. Civil Liberties Union, 542 U.S. 656, 665 (2004) ("When plaintiffs challenge a content-based speech restriction, the burden is on the Government to prove that the proposed alternatives will not be as effective as the challenged statute."); Turner Broad. Sys., Inc. v. FCC, 512 U.S. 622, 662 (1994) ("[A] content-neutral regulation will be sustained if "it furthers an important or substantial government interest; if the governmental interest is unrelated to the suppression of free expression; and if the incidental restriction on alleged First Amendment freedoms is no greater than is essential to the furtherance of that interest.'" (quoting United States $v$. O'Brien, 391 U.S. 367,377 (1968)))

117. "As a general rule, laws that by their terms distinguish favored speech from disfavored speech on the basis of the ideas or views expressed are content based." Turner Broad. Sys., 512 U.S. at 643. "Government regulation of expressive activity is content neutral so long as it is "justified without reference to the content of the regulated speech." Ward v. Rock Against Racism, 491 U.S. 781, 791 (1989) (quoting Clark v. Cmty. for Creative Non-Violence, 468 U.S. 288, 293 (1984)).

118. See Bartnicki v. Vopper, 532 U.S. 514, 544 (2001) (Rehnquist, J., dissenting) (contrasting the more lenient approach for content-neutral regulations with the more hostile strict security standard of content-based regulation).

119. Turner Broad. Sys., 512 U.S. at 662.

120. See James R. Ferguson, Government Secrecy After the Cold War: The Role of Congress, 34 B.C. L. REv. 451, 452 (1993) ("Although this issue has obvious First Amendment dimensions, the Supreme Court largely has withdrawn from any significant role in determining the proper limits of government secrecy."). 
Some degree of this judicial deference makes sense. Obviously the Court does not play the same role in foreign policy and national defense as do the other branches of government. As such, it is in a lesser position to determine which information leaks could genuinely imperil national security. ${ }^{121}$ The Court also recognizes that the Constitution allocates "foreign affairs powers to the political branches."

But while this observation might call for some constitutional tiptoeing, it does not warrant a blank check as to governmental restrictions on national security-related speech, particularly considering the probability that the speech, if not for its national security status, would play an important role in informing the public about government policy and national affairs. The Court is right to recognize national security as a vital government interest, but it also has the responsibility of ensuring that the government protects that interest in such a way that minimizes the infringement of First Amendment liberties. Section 793(e) unnecessarily usurps First Amendment rights, and the Court should compel the government to draft a law that more effectively respects this balance.

\section{Analyzing the Legislative Intent of the Espionage Act and its Application to the Media}

Another argument that weighs against using $\S 793(\mathrm{e})$ of the Espionage Act against the press derives from the legislative history of the statute. Pertinent parts of the legislative record indicate that Congress did not intend to use the Act against the media.

\section{The Press Censorship Provision}

In 1917, Congress almost passed the initial Act with an explicit press censorship provision. ${ }^{123}$ President Wilson argued that the "authority to exercise censorship over the press ... is absolutely necessary to the

121. See N.Y. Times Co. v. United States, 403 U.S. 713, 728-29 (1971) (Stewart, J., concurring) ("If the Constitution gives the Executive a large degree of unshared power in the conduct of foreign affairs and the maintenance of our national defense, then under the Constitution the Executive must have the largely unshared duty to determine and preserve the degree of internal security necessary to exercise that power successfully.")

122. Ferguson, supra note 120 , at 452.

123. See supra Part II.A (detailing Congress's rejection of the press censorship provision). 
public safety."124 Congress, nevertheless, defeated the provision after a flurry of First Amendment debate. ${ }^{125}$

The provision Congress defeated bears some similarity to how certain elements within the government would interpret $\S 793(\mathrm{e})$ today. That provision would have allowed the government to prosecute the press for publishing information that "the President, in his judgment, declared to be 'of such character that is or might be useful to the enemy." "126 The imagination does not have to stretch too far to note the similarity between information that "is or might be useful to the enemy" and $\S 793(e)$ 's reference to information that "could be used to the injury of the United States or to the advantage of any foreign nation."127 Arguably, in fact, $\S 793(\mathrm{e})$ casts a broader net over materials subject to restriction, encompassing information and materials "relating to the national defense," whereas the defeated Press Censorship Provision limited its scope to what "might be useful to the enemy."

Section 793(e), of course, does not give the President unilateral authority to determine which information is or is not protected, and, at least with respect to intangible information, it does have the specific intent requirement that the guilty party have "reason to believe [the information] could be used to the injury of the United States or to the advantage of any foreign nation" 128 Nevertheless, it is the executive branch that is responsible for classifying most information, ${ }^{129}$ and so in actuality, if the government could use the subsection to prosecute the media, the power to do so would still reside primarily in the Executive.

\section{The 1950 Amendment}

Congress passed the Act's 1950 amendment, which introduced $\S$ 793(e), at the height of Cold War paranoia. In amending the Act, Congress once again had the opportunity to explicitly proscribe media publication of national defense information, and once again, it refused to

124. Stone, supra note 20, at 349 (quoting Wilson Demands Press Censorship, N.Y. TIMES, May 23,1917 , at 1 (quoting a letter from Woodrow Wilson to Rep. Webb)).

125. See supra Part II.A (describing the substance of the debate over the press censorship provision).

126. Stone, supra note 20 , at 345 (quoting the press censorship provision as presented to Congress).

127. 18 U.S.C. $\$ 793(\mathrm{e})(2000)$.

128. Id. (emphasis added).

129. See 5 U.S.C. $\S 552$ (b)(1)(A) (2000) (exempting from Freedom of Information Act information that is "specifically authorized under criteria established by an Executive order to be kept secret in the interest of national defense or foreign policy"). 
do so. Moreover, just as with the original 1917 act, legislative history indicates that this refusal was not an unconscious omission. According to Professors Edgar and Schmidt, Jr., "fears that the new subsections 793(d) and (e) might make criminal actions taken by newspapers in 'the normal course of their operations' were rebutted by statements by the Attorney General and by the Legislative Reference Service."130

Additionally, the 1950 amendment to the Act also included a provision that explicitly protected the press, declaring that:

Nothing in this Act shall be construed to authorize, require, or establish military or civilian censorship or in any way to limit or infringe upon freedom of the press or of speech as guaranteed by the Constitution of the United States and no regulation shall be promulgated hereunder having that effect." 131

Thus, just as with the initial act in 1917, it does not appear that Congress foresaw prosecuting the press by virtue of the amendments it added in 1950.

\section{The Policy Considerations Underlying the Issue of Media Liability Under the Act}

The significance of the "free press" is something that commentators and political figures have been opining about since the country's formation. The founders thought enough of the concept to mention the "free press" separately in the Bill of Rights. They saw a special importance in the role of the press. Otherwise, they might have plugged in "free speech" and left it at that, assuming logically that the right of the press would be subsumed therein.

But they saw more than typical free speech interests at stake in this context; they viewed the press as a check on government power. ${ }^{132}$

Exerting the force of public opinion between elections or in place of impeachment, an independent 'fourth branch' of government was seen as helping enforce the formal and informal rules of just politics. A free press "subject only to liability for personal injuries," Thomas Jefferson

130. Edgar \& Schmidt, Jr., supra note 33, at 1030.

131. Subversive Activities Control Act of 1950, Pub. L. No. 831, § 1, 64 Stat. 987, 987.

132. Jeffery A. Smith, War and Press Freedom: The Problem of Prerogative Power 28 (1999). 
said, brings public officials before the "tribunal of public opinion" and thereby "produces reform peaceably ...."

Inexplicably, the Court has never formally recognized the press as an entity with distinct constitutional rights, ${ }^{134}$ although some would say the Court's decisions implicitly make this recognition. ${ }^{135}$ But the Framers' view of the press's importance persists in modern times. Justice Potter Stewart posited that " $\mathrm{t}]$ he primary purpose of the constitutional guarantee of a free press was . . . to create a fourth institution outside the Government as an additional check on the three official branches."'136 "A fundamental tenet of our First Amendment tradition is that the press does not simply report what public officials say, but acts instead as a 'watchdog' over the government.", 137

Thus, at play with respect to the Espionage Act are two competing policy interests: on one side, the inviolability of the free press and its role in enforcing government transparency and public political participation, and on the other side, national security. Both are of paramount importance, and so the natural goal would be that infringement on one interest in favor of the other would be as unrestrictive as possible.

The media's role in checking the government becomes more important in contexts where the branches of the government are less capable of checking themselves. As noted earlier, the power to designate information as "secret" for the purposes of national defense is mostly a province of the Executive, one which it exercises quite liberally. The government is incredibly effective at producing secret information. In 1997, Senator Daniel Moynihan noted that the government created $6,610,154$ secrets in one year $-98.6 \%$ of those via executive order. ${ }^{138}$ In 2004 , the government classified documents 15.6 million times, spending $\$ 7.2$ billion to secure the information. ${ }^{139} \mathrm{~A}$ vigilant and active press acts

133. Id.

134. See David A. Anderson, The Origins of the Press Clause, 30 UCLA L. Rev. 455, 456 (1983) (stating that the Supreme Court has declined to give independent significance to the "freedom of the press" clause found in the First Amendment).

135. See, e.g., Potter Stewart, "Or of the Press", 26 Hastings L.J. 631, 633 (1975) (arguing that the freedom of the organized press has a distinct role under the Constitution as recognized by Supreme Court decisions).

136. Id. at 634 .

137. Jonathan Mermin, Free But Not Independent: The Real First Amendment Issue for the Press, 39 U.S.F. L. REV. 929, 929 (2005) (citing Leathers v. Medlock, 499 U.S. 439, 447 (1991)).

138. 150 CONG. REC. S9700-02, S9715 (daily ed, Sept. 27, 2004) (statement of Sen. Wyden).

139. OPENTHEGOVERNMENT.ORG, SECRECY REPORT CARD 2005: QUANTITATIVE INDICATORS OF SECRECY IN THE FEDERAL GOVERNMENT 1 (2005). 
as a check on this significant power. As Justice Stewart notes in the "Pentagon Papers" case: "In the absence of the governmental checks and balances present in other areas of our national life, the only effective restraint upon executive policy and power in the areas of national defense and international affairs may lie in an enlightened citizenry ... .$" 140$ Punishing the media for publishing national defense-related information without providing clearer and narrower restrictions unfairly undermines the media's ability to serve this important purpose.

Those officials who would support using the Act to prosecute the media frequently reference the advent of the War on Terror. ${ }^{141}$ Clearly, the War on Terror presents unique challenges related to government intelligence and national security that are applicable to the Espionage Act, but so too did World War One, which ushered in the original Act, and the Cold War, which ushered in the Act's most significant amendment.

The truth is the government can always find justification for secrecy. Times change but the underlying reasoning remains the same. The CIA was talking about the "proliferation of terrorism" as justification for "clandestine activities" more than a decade before the attacks of September 11,2001-in addition to "heightened Soviet intelligence profile, changes in Eastern Europe. . . , narcotics, Third World arms production and regional conflicts." 142

Equally timeless are the First Amendment arguments for the public's right to know-arguments that perhaps become even more important specifically at those junctures where the government claims a heightened need for secrecy, instances where "there may well be a confusion of the interests of the administration in power with the interests of the nation." 143 Given the breadth of the Act and judicial deference to its authority, there seems a high likelihood of abuse - of the government

140. N.Y. Times Co. v. United States, 403 U.S. 713, 728 (1971) (Stewart, J., concurring).

141. Representative Oxley opined:

Unfortunately, a one-day story in the New York Times can ruin years of careful work by those who work to map terrorist networks and the flow of terrorist money. Obviously, the editors of the New York Times are more concerned about their sagging circulation rates and about damaging the Bush administration than they are about disrupting terrorist financing.

152 CONG. REC. H4875-02, H4876 (daily ed. June 29, 2006) (statement of Rep. Oxley).

142. Klein, supra note 89 , at 434.

143. David H. Topol, Note, United States v. Morison: A Threat to the First Amendment Right to Publish National Security Information, 43 S.C. L. REV. 581, 600 (1992) (quoting Thomas I. Emerson, National Security and Civil Liberties, 9 YALE J. WORLD PUB. ORD. 78, 80-81 (1982)). 
relying on the "broad concept of national security to justify secrecy decisions based on political considerations."

The problems do not necessarily have to stem from conscious abuse. For instance, consider the issue in the context of the NSA domestic wiretaps story in The New York Times. ${ }^{145}$ Is this a case of a media outlet publishing information that legitimately threatens national security or a case of the government trying to conceal questionable conduct that would open it to public criticism? Or is it both, and if so, in which category does it fit better? These are nuanced questions that lack hard and fast answers. Certainly they are issues that should preclude application of one-size-fits-all secrecy laws that not only give the government broad authority to impose secrecy but also broad prosecutorial power to enforce it.

\section{ANALySIS: REFINING THE STATUTE: POTENTIAL SOlUTIONS}

\section{A. The General Premise}

Admittedly, there is cogency in the notion of a completely unrestricted press, and there are commentators, such as University of Richmond Law Professor Rodney A. Smolla, who advanced such an argument:

Respect for the structural independence of the media contemplated by the Constitution prohibits courts from conscripting journalists as leakpolice. A bright line is required here. The journalist cannot be forced to ask the government source who hands her the document: "Are you sure this is legal? Are you sure this is not under seal? ${ }^{146}$

The bright line Smolla advocates does not concern the nature of the information in question at all, but rather how journalists acquire it. If they steal it, they are "subject to whatever generally applicable legal penalties may apply." 147 On the other hand, if someone simply hands them the information, they "may examine it and publish it."

144. See Ferguson, supra note 120, at 462 (discussing the Executive's "incentives to avoid embarrassment and political setbacks by concealing evidence of failures, mistakes and misconduct”).

145. Risen \& Lichtblau, supra note 18.

146. Rodney A. Smolla, Information as Contraband: The First Amendment and Liability for Trafficking in Speech, 96 NW. U. L. REV. 1099, 1168-69 (2002) (citation omitted).

147. Id. at 1169 .

148. Id. 
These arguments definitely ring with a certain amount of libertarian appeal, but perhaps a more apt approach is that advocated by Zechariah Chafee, Jr. only a couple years following the passage of the original Espionage Act: "[L]et us recognize the issue as a conflict between two vital principles, and endeavor to find the basis of reconciliation between order and freedom." 149 Few would argue that the government has no legitimate interest in protecting national security information from disclosure, and few would argue that the free press does not, itself, also serve a vital societal interest. Thus, the logical goal is balance, and if the problem with the Act, in particular, is overbreadth and vagueness, the solution is to narrow it with judicial or congressional refinement.

\section{B. Congressional Refinement}

Of these, congressional refinement is the preferred solution. Additional judicial construction could also be beneficial, but the problem is that "while the broad literal meaning of the subsections is almost certainly unconstitutionally vague and overbroad, the statutory language does not point toward any one confined reading as a means of saving them." 150 Thus, revision is more properly within the ambit of congressional responsibility. In this way, Congress ensures that whatever law emerges is an accurate reflection of its intent and not merely speculative judicial construction.

The focus of the refinement should emphasize more precise definitions of "information relating to the national security" and "injury" in the context of information that "could be used to the injury of the United States." The easiest way to clarify "national security" is probably to delineate specific situations or types of content that implicate the broader concept. For instance, Congress might proscribe the communication or publication of information related to waging war or nuclear power or intelligence activities where imprudent revelations could put operatives in jeopardy. ${ }^{151}$ Of course, war, itself, is an ambiguous term and would require more specific descriptions of prohibited communication, such as that pertaining to troop movements or technology, for example. Statutory models that cast the national security

149. Zechariah Chafee, Jr., Freedom of Speech in War Time, 32 HARV. L. REV. 932, 937 (1919).

150. Edgar \& Schmidt, Jr., supra note 33, at 1000.

151. See Susan F. Sandler, Note, National Security Versus Free Speech: A Comparative Analysis of Publication Review Standards in the United States and Great Britian, 15 BROOK. J. INT'L L. 711 , 749-50 (1989) (arguing for the creation of new governmental agencies that could develop guidelines for these situations). 
issue in a narrower light already exist. One such statute is another provision within the Espionage Act, $\S 798$, which specifically prohibits publishing certain information about the country's intelligence activities. ${ }^{152}$

Beyond a more precise definition of "information relating to the national defense," the legislature may also give greater clarity to the concept of information disclosures that "could be used to the injury of the United States." One advocated approach is to only allow prosecution in cases where serious harm actually occurs and the government can demonstrate a causal connection between the harm and the disclosure. ${ }^{153}$

The ideal revision would incorporate both methods of refinement. Alerting people to specific situations that implicate national security interests would put them on notice as to when they might be acting within the scope of the statute. Requiring some measurable harm to occur as a result of their disclosure would correct the potentially fuzzy application of the Act as it exists now, where a court can find guilt even for disclosures that merely could cause harm. The statute might even go further and specify particular types of harm that would result in liability, such as revealing information that causes loss of life or affords some sort of measurable advantage to an enemy, and it could authorize a balancing test weighing the negative consequences of the disclosure against any positive ones, such as its service to the public interest. Such a statute would strike a better compromise between the interests of free speech and free press and the secrecy that national security sometimes necessitates.

152. See supra note 32 (containing the text of 18 U.S.C. $\$ 798(a)$ (2000)). It is worth noting that the constitutionality of $\S 798$ is also a matter of debate. At a Senate Judiciary Committee hearing, journalist Gabriel Schoenfeld declared it "free from all the ambiguities and constitutional problems that beset the 1917 Espionage Act." Examining DOJ's Investigation of Journalists Who Publish Classified Information: Lessons from the Jack Anderson Case Before the S. Comm. on the Judiciary, 109th Cong. (2006) (statement of Gabriel Schoenfeld, Senior Editor, Commentary), available at judiciary-senate.gov/hearing.cfm?id=1928. Meanwhile, journalist Jack Shafer cast doubt on the constitutionality of the statute, raising discussion of the vagueness and overbreadth doctrines. Jack Shafer, Bill Keller in Chains, SLATE, Mar. 9, 2006, http://www.slate.com/id/2137792.

153. See James A. Goldston, Jennifer M. Granholm \& Robert J. Robison, A Nation Less Secure: Diminished Public Access to Information, 21 HARV. C.R.-C.L. L. REV. 409, 449 (1986) (arguing for general application of a three-pronged test that subjects actors to prosecution only when "(a) the disclosure has resulted in direct and irreparable damage to the nation's military security; (b) such damage clearly outweighs the contribution to public debate and understanding; and (c) the accused intended to impair the national defense capability"); see also David R. Dow \& R. Scott Shieldes, Rethinking the Clear and Present Danger Test, 73 IND. L.J. 1217, 1218-19 (1998) ("The Free Speech Clause should protect all speech unless three conditions are satisfied: (1) the speaker's specific intent in uttering the speech is to cause an unlawful injury, (2) the injury in fact occurs as a proximate result of the speech, and (3) the speaker, through his or her speech, overwhelmed (i.e., controlled) the will of the listener."). 


\section{Judicial Refinement}

Of course, while statutory refinement may be the optimal solution, in the meantime, defending the First Amendment is the obligation of the Court. In his "Pentagon Papers" opinion, Justice Black offers the following quote of James Madison: "If they (the first ten amendments) are incorporated into the Constitution, independent tribunals of justice will consider themselves in a peculiar manner the guardians of those rights; they will be an impenetrable bulwark against every assumption of power in the Legislative or Executive . . .".154 Presumably, "every assumption of power" includes the restriction of information in the interest of national security.

In this case, as the central problem of the statute is the unwieldy range of information it potentially restricts, the solution is to narrow the restriction. The judiciary could accomplish this in several ways. The simplest, from its perspective, would be to push the matter back to the legislature by finding the statute to be facially overbroad or void for vagueness. However, considering that the relevant precedents have unanimously rejected these claims, ${ }^{155}$ so extreme a turnaround seems an unlikely hope.

The subtler approach would be the one that courts have already taken-narrowing the provision through judicial construction. Although the results have been arguably dubious, courts have already worked somewhat to shrink the specter of "information relating to the national defense." 156 By giving some narrowing effect to what constitutes harm to the United States, they might have some real impact on lending the provision a more navigable, First Amendment-friendly breadth.

In the context of media cases, courts might also consider how a journalist acquires the information as relevant to the inquiry. For instance, courts might grant greater latitude to the press in circumstances where acquisition of the sensitive information was lawful-i.e., in circumstances where a government source voluntarily leaks the information - than in situations where acquisition was unlawful, such as when a journalist steals a secret document. Such a distinction would be consistent with Supreme Court precedent, which, while not addressing

154. N.Y. Times Co. v. United States, 403 U.S. 713, 718 n.5 (1971) (Black, J., concurring) (quoting 1 ANNALS OF CONG. 439) (alterations in original).

155. See supra Part III.B.1-2 (addressing application of the overbreadth and vagueness doctrines to $\$ 793(\mathrm{e}))$

156. See supra Part III.B.1-2 (discussing judicial construction of the phrase "information relating to the national defense"). 
the government's power to punish the publication of unlawfully acquired information, "has repeatedly held that 'if a newspaper lawfully obtains truthful information about a matter of public significance then state officials may not constitutionally punish publication of the information, absent a need ... of the highest order.

Of course, for any limitation to occur, the Court needs to shake itself somewhat of its aforementioned deference to the Executive in matters of national security. In United States v. Robel, ${ }^{158}$ the Court considered a statute that prohibited members of the Communist Party from working at defense facilities. ${ }^{159}$ Congress sought to defend the statute on the grounds that it was passed pursuant to the "war power" established in the Constitution. ${ }^{160}$

Noting the Court's historical deference to the war power, Chief Justice Warren nevertheless struck down the provision as overbroad, admonishing Congress that the "war power' cannot be invoked as a talismanic incantation to support any exercise of congressional power which can be brought within its ambit." security" can take on a talismanic quality of its own, and while deferring to the legitimate measures the government takes in the name of security, the Court must not sink into an "executive-judicial partnership" by ratifying the illegitimate measures. ${ }^{162}$ In the context of $\S 793(\mathrm{e})$, the court can fulfill this responsibility by placing greater limitations on the information that the provision restricts.

\section{CONCLUSION}

The Espionage Act has remained largely unchanged for nearly a century, § 793(e), in particular, for nearly sixty years. In its current state, the Act poses a growing threat to the interests of the free press, a threat that inevitably will be manifested if Congress or the courts do not take action to prevent it. Judicial decisions analyzing the Act, if anything, have become less deferent to the First Amendment, choosing instead to

157. Bartnicki v. Vopper, 532 U.S. 514, 527-28 (2001) (quoting Smith v. Daily Mail Publ'g Co., 443 U.S. $97,103(1979)$ ).

158. 389 U.S. 258 (1967).

159. Id. at 260 .

160. Id. at 263 .

161. Id.

162. See Edgar \& Schmidt, Jr., supra note 84, at 394 (noting that the "Executive's recent efforts to apply the murky espionage statutes to government employees-possibly leading to prosecution for press publications - has been aided by a Judiciary equally unwilling to construe the statutes more narrowly"). 
bow to the government's conception of national security. Rosen, while still young in its proceedings, represents the latest stage of this trend, allowing, for the first time, the application of the Act against nongovernment officials. Conceivably, the next step could be prosecution of the press for publishing national security information. If the Pentagon Papers case is really a "loaded gun pointed at newspapers and reporters who publish foreign policy and defense secrets," Professors Edgar and Schmidt, Jr. suggest it is, then perhaps Rosen is the courts effectively pulling back the hammer.

Undoubtedly, a degree of secrecy certainly benefits national security. But it is just as certain that too much secrecy harms it. ${ }^{164}$ In light of this, the breadth and vagueness of § 793(e) are too much. As even Judge Ellis concedes in Rosen, "the time is ripe for Congress to engage in a thorough review and revision of these provisions." 165 However, if Congress fails to act, the responsibility falls to the courts as the protectors of the First Amendment. Zechariah Chafee, Jr. found the proper balance nearly ninety years ago, when following passage of the Espionage Act, he said, "[T]he great interest in free speech should be sacrificed only when the interest in public safety is really imperiled, and not, as most men believe, when it is barely conceivable that it may be slightly affected."166

163. Edgar \& Schmidt, Jr., supra note 33, at 936.

164. See, e.g., Goldston, Granholm \& Robison, supra note 153, at 450 ("The nation's security, as conventionally understood - encompassing both the technical fitness of its military forces as well as the strategic image which the nation projects among allies and adversaries-has been impaired by the secret formulation of poorly conceived policies. Had the policymaking apparatus accommodated more criticism in open debate, it is likely that, at least in some instances, waste and ineptitude could have been discovered, flawed conceptions of national objectives might have been corrected, and policies that better enhanced national security might have been pursued."). The article cites specific examples, including President Kennedy's statement to the managing editor of The New York Times that more extensive publication about the Bay of Pigs operation might have saved the government from making its "“colossal mistake." Id. at 451 (quoting FRED W. FRIENDLY \& MARTHA J.H. Elliott, The Constitution: That Delicate BalanCE 61 (1984)).

165. United States v. Rosen, 445 F. Supp. 2d 602, 646 (E.D. Va. 2006).

166. Chafee, Jr., supra note 149 , at 960 . 